\title{
100 years of Carte Rouge - a Hungarian ethnographical map by Pál Teleki
}

\author{
Dániel Zoltán Segyevy ${ }^{a}$ \\ ${ }^{a}$ Leipzig University (Leipzig, Germany), segyevy.daniel@gmail.com
}

Keywords: Thematic maps, ethnic relations, critical cartography, peace-negotiations after the WWI, Carpathian Basin

\section{Abstract:}

The Carte Rouge ${ }^{1}$ is one of the most notorious Hungarian ethnographical maps to date. The map was planned and executed by Count Pál Teleki (1879-1941) in 1918. Teleki, who was the chief secretary of the Hungarian Geographical Society, later served as the prime minister of Hungary twice within his political career. The first edition of this particular map was published on the $21^{\text {st }}$ of February in 1919. ${ }^{2}$ Teleki played a central role in arranging, ascribing and allocating Hungarian geographical works for the peace-negotiations following the First World War. The term "Carte Rouge", derives from the French; critiquing the subjective colouring of the map. During this period of time, political correspondents and those in power were responsible for planning such maps in order to support their own political programs with regards to their respective national ties and territorial claims.

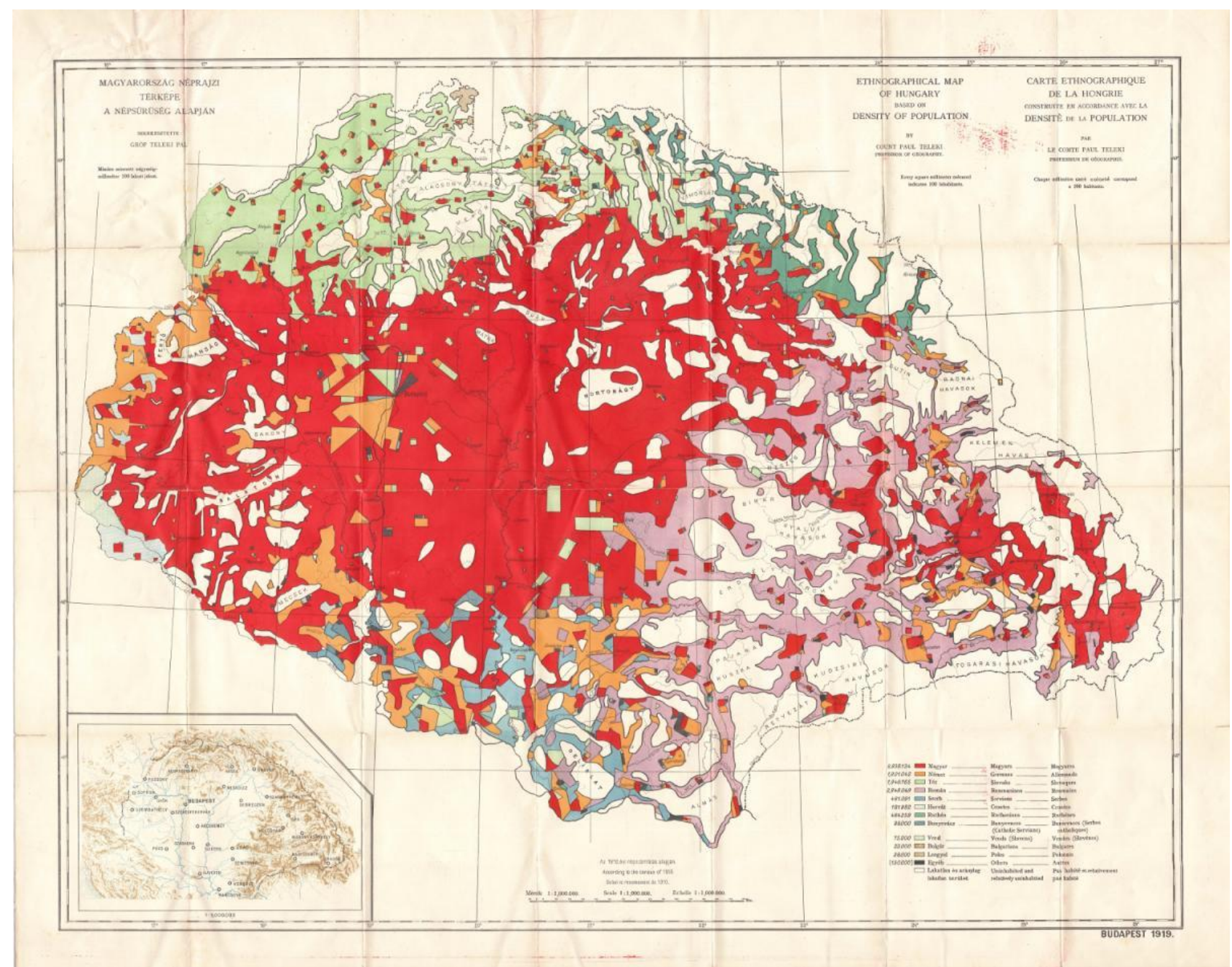

Figure 1: Paul Teleki: Ethnographical map of Hungary based on density of population. 1919.

From the author's private collection

\footnotetext{
${ }^{1}$ Teleki, Pál: Ethnographical map of Hungary based on density of population. Budapest, Hungarian Geographical Institute, 1919.4. $1: 1000000.57 \times 79 \mathrm{~cm}$.

${ }^{2}$ Dániel Zoltán Segyevy: Carte Rouge 100. Teleki Pál vörös térképének hatástörténeti elemzése. In: Regio. 2018/4. 118.
} 
The red pockets on the map signify areas which designate nationality, ethnicity, and language claims, on the part of both the locals and/or the author of the map. Particularly of note, is that this map was viewed and used by the leading politicians of the Entente-powers.

On the $16^{\text {th }}$ of January in 1920 , the day on which the Hungarian delegations received the peace terms of the First World War, Albert Aponyi gave a speech of significant weight in front of the Entente representatives in Paris, after the peace terms were recieved. Aponyi (1846-1933), who was the head of the Hungarian delegation, showed this particular map to those present at this meeting following his speech, as justification and proof of his points. Apponyi sent the map to Teleki and to the members of various delegations. Isaiah Bowman (1878-1950), for example, also had a private copy of the map. Bowman's critique of Teleki's ethnographical map is most significant in this discussion:

„, This idea has occurred to me since examining a map by Count Teleki which gives altogether a wrong impression of the distribution of Magyars in Transylvania that we ought to keep a fairly good collection of propaganda maps, of which I have here several very striking examples, and sometime after I return I should like to write a little paper on the various types of lies and liars that I met in this form of cartography. It would be good popular education, because so many people regard what appears on a map as gospel truth, and almost none of the people, who print maps, understand map technique sufficiently well to distinguish between the various principles followed in the construction of maps. (...). "’3

It is not certain as to whether Bowman was indeed writing about this particular map, however Teleki had at that point and time- edited no other ethnographical map. Others, for example, the Austrian Randolf Rungaldier (1892-1981) had a very positive opinion about the Carte Rouge. ${ }^{4}$

In total, and to the best of my knowledge, the Carte Rouge has 12 editions and 27 various versions.

In the following analysis, I will consider how the Carte Rouge can be compared to other, similar international examples of the region, based on archival research I conducted in Paris, London, Budapest and Milwaukee. For instance, Emmanuel de Martonne (1873-1955), who also adopted a critical approach to the Carte Rouge, planned a comparable ethnographical map of Romania. This map used another method of cartographic representation; nonetheless, the various territorial concepts designated by the colour-selection, the borders and the represented (and not represented) territories are facets that have similar features.

Later Teleki - as member of the Mossul-Commission - designed an ethnographical map of the Turkish-Iraqi border-area, which afforded him international professional recognition. The method of cartographic representation was the same, as was utilized in the creation of the Carte Rouge. ${ }^{5}$

Resultantly, the Carte Rouge inspired the production of other ethnographical maps in Hungary as well as in other countries. In Hungary, Ferenc Fodor (1887-1962) - as the member of the Hungarian Peace-Preparation Office (Békeelőkészítő Iroda) - edited a manuscript map about Central-Europe using the same "representing-method". This map was published under the name of G. Bery in 1938. A part of this map was also reused as a propaganda poster. Later, during the Second World War Imre Jakabffy (1915-2006) continued this form of mapping with a slightly modified version of this method of cartographic representation at the Institute of Political Science (Államtudományi Intézet) in Budapest. Subsequently, other ethnographical maps were edited using this method of cartographic representation by the French and by Romanians.

In sum, this map was a typical product of the period, as it supported a particular territorial concept. The opinions about the map - not independent from the political context - were very differential in form. Regardless, this method of cartographic representation had an extended international carrier in the fields of geography and cartography for years to come afterwards.

\footnotetext{
${ }^{3}$ UWM-American Geographical Society Library (Milwaukee), Correspondence between Isaiah Bowman and W. L. G. Joerg. AGSNY AC 1, 185. box, 38. folder, 7. letter.

${ }^{4}$ Rungaldier, Randolf: Graf Teleki, Ethnographical map of Hungary, based on density of population. 1:1,000.000. Budapest 1922. In: Mitteilungen der Geographischen Gesellschaft. 1923/4. 146.

${ }^{5}$ Gercsák, Gábor - Klinghammer, István: Der ungarische Geograph Pal Teleki als Mitglied der Mossul-Kommission. In: Cartographical Helvetica. 19. 1999. 17-25 p.
} 